\title{
Dissimilar Public Management Paradigms, Similar Adoption: Finding an Approach Contingent on Policy Goals
}

\author{
Yoonho Kim*
}

\begin{abstract}
Several management paradigms - traditional public administration, new public administration, new public management (NPM), and networked governance-have been leaders in practice and in the academic world of public administration at different time periods. However all these management paradigms have a negative aspect in common - a "one-size-fits-all" approach to government reforms. This study tries to overcome this approach, utilizing a contingent method. Each of the four paradigms has been suggested for adoption in one or two areas of different policy types based on a two-by-two table with the dimensions of high and low with respect to market mechanisms and high and low on the explicitness of the politics-administration dichotomy. The study proposes that traditional public administration would be the appropriate choice in the areas of redistributive and constituent policy. New public administration would work well for regulatory policy, whereas networked governance and NPM (customeroriented practices) would be the right choice in the arena of distributive policy.
\end{abstract}

Keywords: traditional public administration, new public administration, NPM, network governance, regulatory policy, distributive policy, redistributive policy, constituent policy, contingent approach

\section{INTRODUCTION}

Once accepted as a novel public-sector reform movement in the early 1990s, new public management (NPM) has been "new" for so many years that it is now acknowledged as a "middle-aged" concept. Dunleavy, Margetts, Bastow, and Tinkler (2005, p. 468) have even declared that "New Public Management is dead" and that "the torch of leading-edge change has passed on from NPM and will not return." Accordingly, some scholars have identified a newly emerging management paradigm that they refer

\footnotetext{
* Yoonho Kim is an associate professor of public administration at the University of Seoul. Email: ykim@uos.ac.kr.
}

Manuscript received February 28, 2016; out for review March 10, 2016; review completed April 5, 2016; accepted April 16, 2016.

The Korean Journal of Policy Studies, Vol. 31, No. 1 (2016), pp. 63-85.

(C) 2016 by the GSPA, Seoul National University 
to as "public value management" (Stoker, 2006) or "new public service" (Denhardt \& Denhardt, 2003), which centers its practice on a system of interactions between relevant actors and features networked governance.

However, we should note that in any era the dominant paradigm is not a panacea. That is, currently popular management thinking is not applicable to all management practices. In real situations, there is no one best answer but many possible solutions (Behn, 1998, p. 140). Methods and actions should fit circumstances because outcomes generally vary according to them (Alford \& Hughes, 2008, p. 138). This argument is supported by studies comparing various public service areas in terms of the degree of reform success (Syrett, Jones, \& Sercombe, 1997; Pollitt, Birchall, \& Putnam, 1998; Jones, 2001; Walker, 2001; Walker \& Enticott, 2004). Any management reform or social intervention can be effective in some situations while producing unfavorable consequences in others. This suggests a need for avoiding the "one-size-fits-all" approach to government reforms in which reformers engage in the uncritical and universal adoption of reform methods. Many scholars have made this argument (e.g., Hood \& Peters, 2004; Stoker, 2006; Alford \& Hughes, 2008), but few have provided guidance on how to solve the problem.

The present study proposes a new but integrative approach to applying various public management paradigms that consider situational factors. The proposed approach is integrative in that it does not rely on just one management paradigm. Instead, it takes into account all management paradigms considered in the analysis because each has its own strengths and weaknesses. That is, all paradigms occupy their own niches where they can be applied effectively (strength) but are less successful (weakness) in non-niche areas. For situational factors, I have adopted policy goals. All management approaches have to deal with various policy areas, including agriculture, industry, housing, defense, international relations, government restructuring, housing, social services, and social security. All policy initiatives have their own purposes or goals that can be generalized as regulatory, distributive, redistributive, and constituent, among others, based on Lowi's $(1972 ; 1985)$ policy scheme. It is legitimate to use his scheme here because policy researchers have generally accepted it and (more importantly) it incorporates the critical fact that all policy initiatives are goal oriented.

I present this study's exploration of the relationship between management paradigms and policy goals in four parts. First I consider the historical development of management paradigms from traditional public administration through new public administration and NPM to networked governance. I then classify management paradigms into four quadrants of a two-by-two table based on two dimensions: the politics-administration dichotomy and market mechanism. Next, I briefly conceptualize policy types by drawing on Lowi's (1972) well-known policy scheme and provide a theoretical analysis in 
which the match (or fit) between a policy goal and a managerial paradigm is made. Finally, I conclude with some practical suggestions for government reforms and future research.

\section{THE EVOLUTION OF MANAGEMENT PARADIGMS}

\section{Traditional Public Administration}

The traditional public administration approach relies heavily on a Weberian view of the world. The core of Weber's thought lies in the idea that direct democracy is not a viable option for most decision-making processes. Thus, the representative form of democracy-so-called elite democracy-constitutes the heart of traditional public administration. Under elite democracy, competing political leaders define the public interest. This form of representative democracy is supposed to be flexible enough to strike a balance between various interests and cultivate policies that can address changing circumstances (Stoker, 2006, p. 44).

Traditional public administration is in line with the idea of the politics-administration dichotomy. Public managers are agents of elected politicians, and it is presumed that they will faithfully implement the policies that their principals (i.e., politicians) develop through political discussions and debates. Traditional public administration advocates bureaucracy as an effective tool for meeting increasing demands on the modern state. Such demands come mainly from welfare policy areas that can be managed only through the standardization of administrative responses, that is, via a rationallegal bureaucracy.

Bureaucracy ensures organizational effectiveness, such as stability and predictability in a number of ways. First, it institutes a hierarchical division of labor. Through this central feature of bureaucracy, complicated administrative problems are divided into manageable and recurring tasks, and each task is placed under the jurisdiction of a defined office (Beetham, 1987). Second, the management position is considered a full-time vocation or career for the official and features continuity and long-term advancement. Third, there are prescribed rules that govern the work of officials that are meant to ensure that clients (the public) are treated without arbitrariness or favoritism. Fourth, and finally, officials are placed in positions based on merit, not political favoritism, because administrative positions in the bureaucracy generally require expert training and full-time work in each defined area of responsibility. 


\section{New Public Administration}

In the late 1960s and 1970s, amid the increasingly turbulent environment in the United States after the civil rights movement, the traditional public administration approach came under attack by a group of scholars who advocated a philosophy that came to be known as new public administration (Marini, 1971; Waldo, 1971; Meier, 1993, pp. 201-205). Young students sponsored by Dwight Waldo criticized administrators for injustices in the modern state and tried to reframe the value of public administration at a 1968 conference held at the Minnowbrook conference center. According to them, traditional public administration's administrative tools were supposed to have eradicated arbitrariness and political favoritism, but, in fact, they systematically facilitated the biased treatment of races and classes. For example, administrative procedures incorporating the features of impersonality, written forms, and lengthy steps for receiving services or benefits are acceptable to the white middle class but are hurdles for the poor and minority groups (Goodsell, 1981).

Thus, new public administration attempts to promote conditions that can facilitate social equity. In this regard, the movement incorporates values into the jurisdiction of administration. This is quite different from what traditional public administration pursues, namely, the neutrality of administration or neutral competence. To achieve social equity, new public administration may advocate the interests (i.e., enhanced political power and economic well-being) of the disadvantaged or may even call for disregarding those of the better represented by changing those policies and structures that systematically hinder social equity.

Decentralization and ending the status quo are two important measures that can help achieve social equity. First, agencies and their organizational structures should be decentralized so that individuals impacted by a particular program have more control over the program. Maximum feasible participation may be the best example of such client involvement. Frederickson (2010) found that maximum feasible participation can give ghetto residents the impression that they have the ability to influence publicly made decisions that influence their well-being, although it is not justifiable in terms of economy and efficiency. In short, new public administration upholds democratic norms and practices, norms and practices that can be achieved through decentralizing the structure of policy making. Ending the status quo is another measure of new public administration. The most radical form of this measure involves confrontations. A city personnel director may confront the chief of police and the police agency regarding the issue of eligibility standards for new patrolmen, arguing that the height and weight requirements are unrealistic and systematically discriminate against certain minority groups (Frederickson, 2010, p. 14). 
Despite these innovative measures, the idea of new public administration has only found traction among its academic advocates in the field of public administration. That is, politicians and practitioners have rarely endorsed it (Guy, 1989; Daley, 1984; Evans, 1981). Frederickson (2010), a leading scholar of new public administration, has observed that "by the mid-1980s, the phrase 'new public administration' was seldom heard outside of the textbooks" (p. 4). Because it advocates a socially delicate issue (social equity) and employs provocative methods such as confrontation, new public administration may not be able to penetrate the government under its label. That is, new public administration has never been a government-wide and worldwide reform movement, unlike NPM in the 1980s and 1990s.

\section{New Public Management}

The NPM movement across the Western world originated from a critique that public service organizations are inclined to be monopolized by the interests of producers, such as bureaucrats and other rank-and-file employees. According to this critique, public service organizations are likely to be both inefficient in saving public money and unresponsive to the public's demands. A solution to these problems is to shatter the monopolistic structure of public service delivery and construct incentives and tools that can impact the way public service organizations perform (Stoker, 2006, p. 45). Dunleavy et al. (2005, p. 470) identify three main integrating themes in NPM: disaggregation (the division of large public-sector hierarchies into wider and flatter hierarchies as large private firms move from U-shaped to M-shaped structures), "competition" (the separation of purchasers from providers to increase competition among potential providers, which can reduce public provision and diversify suppliers), and "incentivization" (the placing of greater emphasis on pecuniary-based and specific performance incentives). In short, NPM seeks to break down the bureaucratic backbone of the Weberian model of traditional public administration (Stoker, 2006, p. 46) by developing a wider range of service providers and a more market-oriented approach to management.

Despite NPM's efforts to differentiate itself from traditional public administration, it shares an important value as far as governance structure goes, namely, the imperative to keep politics separate from administration. NPM holds that a politician's role is to set rigorous targets and make difficult choices regarding budgets, leaving administration to public managers (Stoker, 2006, p. 46). Just as an ideal Weberian bureaucracy protects its professionals, a good NPM system provides public managers with a degree of management freedom. However, politicians under NPM make the final judgment on the performance of public managers in terms of their goal achievement.

In spite of its intention to reform the practices of traditional public administration, 
NPM produced unintended outcomes. Contrary to what its reformers expected, NPM augmented formalities and increased the number of regulations public agencies were subject to in the late 1980s and early 1990s (Light, 1993; Hood et al., 1999; Jones \& Thompson, 1999). Therefore, advocates of NPM now seldom expect it to improve the overall effectiveness of government (Dunleavy et al., 2005, p. 468). ${ }^{1}$

\section{Networked Governance}

Unlike traditional public administration and NPM, networked governance, an emerging paradigm, incorporates politics into management. The idea of networked governance originates from a concern over how to get public officials to work effectively with politicians (Goss, 2001; Smith, 2003). However, the goal of the effort to integrate the two separate realms is to enhance public value. In this regard, networked governance shares something in common with new public administration, which pursued a public value, social equity.

Under the networked governance paradigm, politics plays a positive role as a mechanism for social coordination. Stoker (2006, p. 47) argues that this is important for three reasons. First, politics enables people to cooperate and make decisions based on something beyond the individualism that drives the market. Second, the flexible nature of political decision making makes it possible to deal with uncertainties, ambiguities, and unexpected changes. Finally, politics builds a social process through which diverse interests are brought together to achieve a common purpose.

Networked governance is understood through the following propositions, which make clear the role of politics in it (Stoker, 2006, pp. 47-49). First, the underlying philosophy of public managers is to create public value (Moore, 1995), to advance favorable social and economic outcomes. An evaluation of the delivery of public value requires debates and deliberations between relevant stakeholders and government officials. Second, networked governance relies on the stakeholder conception of legitimacy in its governance arrangements (i.e., for decision to count as legitimate, all stakeholders must be involved). Third, effective procurement demands an open-minded approach that enables bureaucrats to recognize the best suppliers (regardless of whether they are in the public, private, or voluntary sector), those that can contribute to the promotion of community well-being and meet the needs of individuals (Aldridge \& Stoker, 2002). Finally, there is a need for an adaptable and learning-based approach to public

1. In fact, a number of researchers have identified the limitations of NPM (e.g., Kickert, 1997, deLeon \& Denhardt, 2000, Terry, 1993, Kaboolian, 1998, Thompson \& Riccucci, 1998, Kim, 2010, and Kim \& Kaneko, 2011, pp. 148-149). 
service delivery. The ideal public manager is engaged in a process of continuous evaluation and learning through steering networks of deliberation and delivery. However, his or her ultimate role should be to ensure that his or her action brings about net social benefits.

\section{CATEGORIZATION OF MANAGEMENT PARADIGMS}

\section{Woodrow Wilson's Statements: Two Dimensions}

Wilson's famous essay "The Study of Administration" (1887) defines two critical elements of public administration-the politics-administration dichotomy and the adoption of businesslike practices (or market mechanisms). Wilson asserts that the "field of administration is the field of business. It is removed from the hurry and strife of politics" and "lies outside the proper sphere of politics. Administrative questions are not political questions" even if "politics sets the tasks for administration" ([1887] 1941, p. 20). Through these famous citations Wilson offered the following two important messages. First, although policies are to be discussed and decided by politicians, they should be neutrally implemented through a professional bureaucracy. Second, businesslike practices should guide administration. Here the two elements-the politics-administration dichotomy and the adoption of business-like practices or market mechanism - will be used for the classification of four management paradigms.

\section{The Politics-Administration Dichotomy}

The first message by Wilson (1887) concerns the separation of administrative processes from the influence of politics (i.e., the Congress or the President). The bureaucracy is supposed to limit its duty to administration (Goodnow, 1900). In line with this trend, early reformers developed council-manager plans for local governments in which the council makes policies and the city manager executes it. However, this practice of enforcing a separation between politics and administration increasingly broke down (Denhardt, 1999, p. 17) as public managers started to be drawn into the policy-making process, and after World War II, the distinction became untenable. Waldo (1948), Appleby (1949), Dahl (1947), and Long (1949) thoroughly dismantled the standing of the idealized dichotomy in the field of public administration, rejecting it as a false description of reality. "Public administration," Appleby declared, "is policymaking" (1949, p. 170).

To some extent, public managers' increasing involvement in the policy-making 
process was attributable to the fact that the management of government organizations was becoming more complex, and the legislative branch of government realized the difficulty of being knowledgeable about every facet of government (Denhardt, 1999, p. 17). Consequently, the legislative branch was forced to delegate a substantial portion of its policy-making authority to public agencies that were endowed with technical and professional expertise. However, this sharing of policy-making power with the legislative branch meant that public managers often found themselves caught between the imperatives - efficiency, on the one hand, and responsiveness, on the other, and between bureaucracy, on the one hand, and democracy, on the other.

Public managers are expected to manage public organizations in the most efficient manner possible, getting things done in a prompt and least costly manner. On the other hand, these managers are supposed to be always attentive to the needs of the citizenry regardless of whether those needs are communicated through the chief executive, through the legislature, or directly (Denhardt, 1999, p. 19). Similarly, public managers are expected encourage widespread participation and involvement by citizens in the policymaking process (Redford, 1969, p. 8), but the bureaucratic structure can make this kind of democratic participation difficult. That is, against participation and involvement, there stands the bureaucratic culture of top-down decision-making and authority (Denhardt, 1999, p. 19).

In this sense, these two issues (efficiency vs. responsiveness and bureaucracy vs. democracy) can be subsumed under the politics-administration dichotomy. That is, efficiency and bureaucracy can be seen as facets of administration, whereas responsiveness and democracy can be regarded as aspects of politics. Once the role of public managers in the policy-making process became more apparent after World War II, concerns began to arise over responsiveness and democracy in the administrative sphere. Consequently, the degree of separation between politics and administration will vary in accordance with management paradigms and can be classified into as either high or low.

\section{Market Mechanisms (Businesslike Practices)}

Wilson's claim that the "field of administration is the field of business" ([1887] 1941, p. 20) implies that administration should reflect businesslike practices. Wilson's statement has worked as a powerful justification for reformers who have applied various management techniques and methods used in the private sector to the sphere of public management. That is, these reformers interpret Wilson's statement to mean that public management is not distinct from business administration. Consequently, many government organizations have been designed to resemble private firms (Rainey, 2003, 
p. 59). Many public organizations perform businesslike functions and generate their own revenues through the sale of products and services and other means. Furthermore, the public and private sectors have overlapped and become intertwined in a number of ways in recent years. Through contracts, grants, vouchers, subsidies, and franchises, governments make arrangements for the delivery of health care, sanitation services, research services, and a number of other services in conjunction with private-sector organizations (Rainey, 2003, p. 60). The "commercialization" of government organizations may compromise their public service mission or the public interest. The degree to which government organizations are commercialized or adopt market mechanisms in their practice may vary by the management paradigm they pursue as well and can be classified as high or low.

\section{Classification of the Four Management Paradigms}

Figure 1 shows the combination of the two dimensions discussed thus far (i.e., the politics-administration dichotomy and market mechanisms) resulting in the four categories. Traditional public administration is categorized as high on the politics-administration dichotomy but low with respect to market mechanisms. This management paradigm is classified as high on the politics-administration dichotomy because it is rooted in the idea that the role of public managers ought to be limited to ensuring that rules and procedures are properly followed in the implementation of policies.

Figure 1. Categorization of Management Paradigms

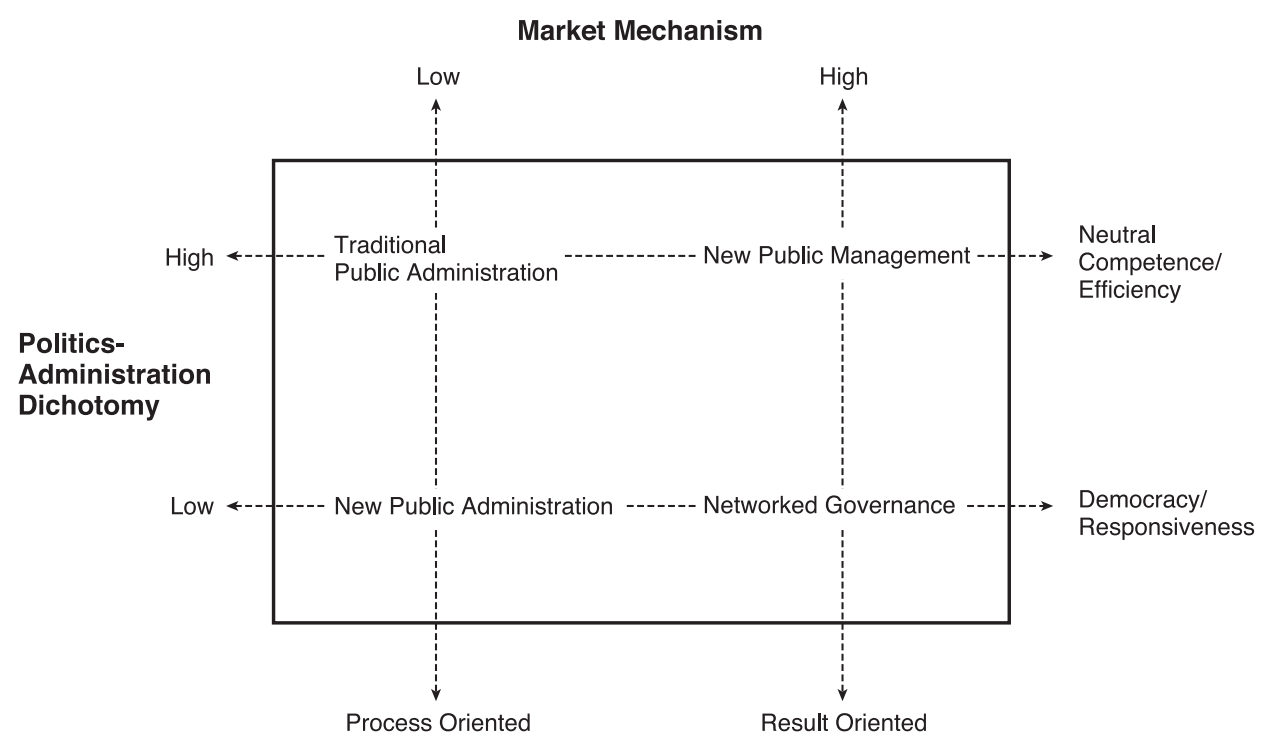

The Korean Journal of Policy Studies 
Furthermore, traditional public administration is categorized as low with respect to market mechanisms because of its nature as a "closed-system" (Rainey, 2003, p. 50; Kettl, 2002, p. 101). The students of the closed system represented by Max Weber liken an organization to a machine "whose own operation is substantially unaffected by its environment" (Kettl, 2002, p. 101). In other words, traditional public administration relies exclusively on its internal structure and operations, such as stability and predictability through hierarchy, and written rules, to achieve organizational effectiveness. In this management paradigm, the external environment, such as the market, is not understood to be an alternative measure of service provision, as it is in NPM or networked governance; thus it is low with respect to market mechanisms.

New public administration is categorized as low on the politics-administration dichotomy as well as with respect to market mechanisms. It is understood as having a low degree of separation between politics and administration because of the emphasis it puts on involvement of employees and clients (in particular, the disadvantaged and the poor) in the policymaking process for the achievement of social equity. That is, under the new public administration, the area of administration is blurred by that of politics. In addition, like traditional public administration the new public administration is categorized as low with respect to market mechanisms because it does not adopt methods of the private sector to deliver public services.

NPM is categorized as high on the politics-administration dichotomy as well as with respect to market mechanisms. This is because, as already noted, the role of public managers in NPM is limited to faithfully implementing what politicians decide (Stoker, 2006, p. 46), and then politicians make the final judgment on what the managers achieved in terms of the goals set by the politicians. In addition, NPM argues for the government's use of means similar to those used in the private sector, a proposition that is based on the assumption that public and private organizations are sufficiently alike (e.g., privatization and contracting: Barzelay, 2001; Kettl, 2002). That is, NPM is a management paradigm that aims to commercialize public management by providing customer-oriented services and by setting performance targets and incentives, among others; thus, it is high with respect to market mechanisms.

Networked governance is categorized as low on the politics-administration dichotomy but high with respect to market mechanisms. It is low on the politics-administration dichotomy because it does not seek to keep politics at arm's length but rather considers it as central to management practices (Stoker 2006, p. 46). That is, under networked governance public managers are supposed to create public value by participating in the policy-making process (Moore, 1995, p. 57). In addition, networked governance is categorized as high with respect to market mechanisms because it has inherited many strategies that emphasize businesslike practices from NPM. For example, networked 
governance uses open competition among the public, private, and voluntary sectors to identify the best supplier. This mechanism ensures that the focus is on end results (Stoker, 2006, p. 48). Moreover, NPM emphasizes a performance culture (which encourages strong commitment to services for individuals and community) to guarantee world-class service delivery (Aldridge \& Stoker, 2002).

\section{Common Features of Management Paradigms}

The high degree of separation between politics and administration shared by traditional public administration and NPM is associated with the value of neutral competence or efficiency (see figure 1). Traditional public administration calls for the establishment of a highly skilled bureaucracy insulated from political interference so that neutral competence or efficiency can be achieved by it. Likewise, NPM also seeks to keep politics out of government agencies so as to enable the achievement of bureaucratic efficiency (Kaboolian, 1998, p. 190). ${ }^{2}$

The low degree of separation between politics and administration, which is shared by new public administration and networked governance, leads to more responsive and democratic governments. It means that the legislative branch is no longer the dominant policy maker but rather shares policy-making power with the administrative branch and others (Meier, 1993, p. 49). Yet the bureaucratic policy-making power delegated by the legislative branch is in turn allocated to individuals and pressure groups, whose participation in the policy-making process has been highlighted as a means of making bureaucracy more responsive and democratic. As demonstrated by the case of maximum feasible participation, new public administration encourages the involvement of the disadvantaged and the poor in the policy-making process to make public management more responsible to their needs. Networked governance calls for a democratic process based on continuous interactions between the government and the

2. However, for traditional public administration, the perceived danger is that politicians outside the bureaucracy are not be able to exercise any real control to ensure its responsiveness to elected officials. For NPM, the dilemma occurs when the system or bureaucracy appears to cease responding to politics, as public mangers pursue their private goals instead of focusing on changing and flexible objectives of the political system (Stoker 2006, p. 55). The problem becomes more severe when broad targets of the system designated by politicians are negotiated with public managers. Therefore, under NPM, citizens are likely to perceive themselves as mere customers who are not permitted to question the goals of service delivery (Stoker, 2006, p. 56). Consequently, NPM rests on a trade-off that makes efficiency the most important goal, reflecting the view that "management is king," a view that sidelines politics (Stoker, 2006, p. 56). 
governed whereby they can learn from each other and produce solutions. Networked governance ensures democracy by opening up the governance system as far as possible to relevant stakeholders.

Traditional public administration and new public administration both embrace process-oriented management practices as a result of their deemphasis on market mechanisms. Process-oriented or rule-oriented management is particularly strict when the organizational goals are conflicting or ambiguous, which is the case under the elite democracy that guides traditional public administration. Under the elite democracy, political leaders are supposed to be flexible enough to balance various interests and make policies that can address changing circumstances. That is, the objectives of public policies made under the elite democracy (i.e., traditional public administration) tend to be conflicting and ambiguous. The difficulty in specifying and measuring policy goals, which makes market mechanisms inappropriate, causes public officials to try to manage agencies by enforcing rigid procedures and rules rather than by evaluating policy outcomes. Thus, under traditional public administration, government manages demands from civil society (e.g., welfare-benefits related services) through the standardization of administrative responses. Prescribed rules govern the work of public officials so that all similar cases are managed in the same way.

New public administration focuses on processes (in this case, political participation rather than rules) as well in its emphasis on the involvement and participation of the socially and economically disadvantaged in the policy-making process for the achievement of social equity. It appears that new public administration is not result oriented since it does not tell us how to determine whether social equity has been achieved. Probably due to its lack of performance measures or its overemphasis on processes, new public administration's maximum feasible participation was largely unsuccessful.

NPM's and networked governance's adoption of market mechanisms leads to more result-oriented government. NPM emphasizes economic rationalism, methods such as strong customer service, performance-based contracting, and reliance on competition, market incentives, and fiscal austerity measures that help make governments "work better and cost less." All these approaches target efficiency, enhanced performance, and customer satisfaction, which are result oriented. That is, the practices of NPM deemphasize processes such as democratic deliberation and standardized rules and focus on ends or targets instead.

Networked governance is also result oriented. Its management paradigm emphasizes democratic deliberation through which various stakeholders are involved in policymaking and policy delivery, but it also adopts many of the market mechanisms associated with NPM. However, they are all means to secure the goal that networked governance 
ultimately pursues - the public interest. The public interest concerns the broader interest of the community and the long-term consequences of policy to it. Thus, in networked governance the most important criteria for assessing management performance is how effectively the management paradigm has advanced the public interest (Denhardt \& Denhardt, 2003, p. 9; Stoker, 2006).

\section{FOURFOLD POLICY SCHEME AND PROPER MANAGEMENT PARADIGMS}

This section analyzes the fourfold policy scheme from the perspective of public management rather than of politics. ${ }^{3}$ For this purpose, it is imperative to illustrate the subject from the standpoint of those that manage or administer each type of policy. In addition, using the features of each type of public policy illustrated, I suggest an appropriate management paradigm for each policy type, thereby matching means to ends by fitting a management paradigm to a policy type.

Lowi's widely used fourfold policy scheme (1972) subdivides public policies into regulatory, distributive, redistributive, and constituent policies. Lowi (1985) argues that the categories of public policy need to be understood as efforts to act on the intentions of state (or rulers) that have been declared in the established lawful language of the government. ${ }^{4}$ Because there is more than one way the state can declare an intention (or more than one way the state can assert its coercive powers through public agencies), there is more than one category of policy.

\section{Regulatory Policies}

Public managers and agencies that administer regulatory policies are responsible for implementing laws restricting unfair competition and preventing the sale substandard goods, for making or implementing rules imposing obligations on citizens, and for providing sanction for nonconformance (Lowi, 1985, p. 85). In addition, the legislative branch is inclined to delegate a great amount of policy-making authority to regulatory agencies partly because legislators perceive that assuming control of regulatory policy

3. The illustrations of the fourfold policy scheme here are based mainly on Kim's (2007, pp. 59-78) study.

4. Lowi (1985) suggests that the classifications of public policy must not consider the likely impacts of such public policies on the polity, society, or economy. Rather, he contents focusing on the goal or intention of public policy. 
may not be politically beneficial for the legislature (Epstein \& O'Halloran, 1999, p. 8). Therefore, legislators set general guidelines, and managers in regulatory agencies expand these vague laws into certain policy actions through rule making (Meier, 1993, p. 85). Since rule making is a quasi-legislative process in which interest groups are heavily involved, regulatory policies create politics of "pluralism."

Regulatory policies are the area where intense politics are involved but no market mechanism appears. As illustrated above, regulatory agencies face harsh conflicts or politics among various interests over the rule-making process, which indicates a low on the politics-administration dichotomy. On the other hand, regulatory agencies formulate and impose rules on citizens or interest groups rather than deliver benefits to them. Thus, regulatory agencies are not in need of market mechanisms, such as privatization or outsourcing, for the accomplishment of their regulatory duties. In turn, it appears that for those working in the area of regulatory policies new public administration would be an appropriate management paradigm to adopt (see Figure 1).

Although both the implementation of regulatory policies and the philosophical basis of new public administration focus on the equity or fairness of those affected by them, their constituencies are not identical. The constituency of new public administration - the disadvantaged and the poor-is narrower than that of regulatory policiesthe general public or interest groups. Consequently, it is recommended that public managers in the sphere of regulatory policy rely on new public administration particularly when their policy targets are socially or economically disadvantaged individuals.

\section{Distributive Policies}

Lowi (1985) regards distributive policies as being virtually the opposite of regulatory ones in mission. That is, distributive agencies are responsible for promoting and fostering the interests of their clientele - that is, providing benefits such as research results, services, grants and subsidies directly to citizens and organizations. Thus, while regulatory agencies' relationship with the public is that of controller and controlled, the relationship between distributive agencies and the public is one of patron and client. Distributive policies can be allocated and disaggregated in a non-zero-sum way or on a unit-by-unit basis. In addition, distributive agencies need a great amount of discretion in order to serve the particular demands of citizens effectively. A localized or decentralized policy-making structure is imperative in the distributive policy realm, and it often comes to be dominated by clients. Lowi (1979, p. 68) concisely illustrates this tendency in the field of agriculture, noting that it is an area "where the distinction between public and private has come closest to being completely eliminated. This has been accomplished not by public expropriation of private domain . . . but by private 
expropriation of public authority."

Networked governance would be most appropriate paradigm for carrying out distributive policies (see figure 1). That is, distributive policies are categorized as less on the politics-administration dichotomy and more on the market mechanism because of their decentralized policymaking process and privatized service delivery system, respectively. The localized policy-making structure of distributive policies may foster the participation of local stakeholders so that policies aimed at community well-being can be made and implemented through social coordination among the community members. On the other hand, distributive benefits are often delivered through privatization or outsourcing (e.g., garbage collection, research consortiums). Networked governance would be an appropriate model for public managers whose job is to implement distributive polices because it focuses on deliberation and learning among stakeholders and encourages taking an open-minded approach in selecting suppliers.

Furthermore, some distributive policy areas should be niches for NPM, particularly its practices that focus on customer oriented services..$^{5}$ Although NPM calls for a high degree of separation between politics and administration (see Figure 1), it stresses "empowering employees to get results" and "decentralizing decision making power" (Rosenbloom, 1998, p. 22), which is signified with one of its key elements, entrepreneurial managers. NPM relies on a decentralized structure to enable individual units in an agency to act as customer service centers (Rosenbloom, 1998, p. 25). In consequence, as public managers become more responsive to customers' demands, the boundaries between public agencies and their external environments tend to become less distinct (Rosenbloom, 1998, 25). This point is, to some extent, associated with what Lowi (1979, p. 68) illustrated about distributive policy area as quoted above. In short, NPM's focus on customer orientation fits the nature of distributive policy that fosters and promotes the interests of their clientele.

\section{Redistributive Policies}

Redistributive policies tax one group of individuals, the employed and rich, to provide benefits to another group, the unemployed and poor. That is, they aim to achieve

5. NPM views the public almost exclusively as customers (Rosenbloom, 1998, 453). But public administration scholars have not often addressed the status of the "public" in the public administrative state (Rosenbloom, 1998, 454). For the most part, traditional public administration treated the public as "cases"- that is, as routinely handled clients who fell into similar categories (Rosenbloom, 1998, 485). NPM transformed the public from cases to customers. In this regard, NPM has made an important contribution in the field of public administration, reinvigorating and strengthening agencies' commitment to service. 
equity in society by balancing power between the "haves" and the "have-nots" (Forester, 1984, pp. 28-29). Redistributive policies (e.g., Medicare, Medicaid, affirmative action, special community development efforts, categorical antipoverty grants, unemployment insurance, and social security) are generally controversial, the source of ideological or class conflicts between liberals and conservatives.

The controversial nature of redistributive policies leads to the centralization of policymaking that confines the development of programs within the legislature. More specifically, redistributive tax programs adopt an "ability to pay" system, such as taxes on luxury items and a progressive income tax. Such redistributive tax programs significantly affect those in the high-income brackets, since a small increase in, say, the income tax in theses high-income bracket will seize a great amount of money from individuals in the bracket. ${ }^{6}$ Thus, legislators tend to enact specific legislation, leaving administrative agencies with no or little latitude to resolve such controversial problems within the legislative branch and limiting the opportunities of agencies to cultivate clientele (McCool, 1990, p. 284). Generally speaking, unlike regulatory and distributive agencies, redistributive agencies do not have mutual exploitation and cooptation with organized interest groups in the private sector because they do not interact with these groups much. Furthermore, their lack of decision-making power leads redistributive agencies to concentrate on mechanically executing policies specified by the legislative branch.

Redistributive policies can be characterized as more in line with a management paradigm that depends on a high degree of separation between politics and administration dichotomy and that does not depend much on market mechanisms (see figure 1). This is because those managing redistributive policies are supposed to faithfully implement what the legislative branch decides and because no salient market mechanism seems to be associated with the delivery of redistributive policies. Thus, it appears that traditional public administration is the best approach for the implementation of redistributive policies.

\section{Constituent Policies}

Constituent policies are conceptually the least mature of the four policy areas. These policies-administrative/departmental reform policies, policies to create agencies and

6. The other examples for which minor changes at the margins threaten great shifts of benefit in the economy of major class interests are fraction of a percent in the discount rate, the modification of a word in the explanation of eligibility, and a change of one element in the composition of the CPI (Lowi, 1985, p. 93). 
administer personnel, and budget policies, for example - are responsible for government itself in that they are organized around not service provision but administrative goals. They aim to benefit the government - that is, the government is the constituency. In turn, unlike other line agencies, constituent agencies have minimal responsibility for making or implementing rules that are associated directly with citizen conduct or status. Constituent agencies rather decide and implement "rules about rules"-i.e., rules applied to line agencies - to support or control the operations of line agencies.

Decision making in constituent policies hinges on interaction among a few rival party leaders, but constituent policies engender relatively little conflict in the legislature because in-house, administrative affairs do not attract much interest or attention from groups outside the government such as electorates or interest groups. Consequently, presidents have greater influence over constituent policies (Spitzer, 1983, p. 150). However, the legislative branch may not delegate much policy-making power to constituent agencies. The amount of power delegated to executive agencies from congressional committees is much lower in the area of civil service (i.e., a constituent policy) than in other areas, such as public health (i.e., regulatory) or science and technology (i.e., distributive) (Epstein \& O’Halloran, 1999, pp. 202-203). Thus, constituent policies accord well with a management paradigm that depends on a high degree of separation between politics and administration. Further, those implementing constituent policies do not adopt market mechanism approaches from the private sector or outsource service deliveries because the nature of constituent policies is administrative. Therefore, the methods and techniques of traditional public administration are appropriate for constituent agencies to use.

Table 1 provides a summary of the preceding discussion connecting policy areas to proper management paradigms. Generally speaking, different public management paradigms have different policy niches. New public administration matches regulatory policy, networked governance and NPM (particularly, customer oriented practices) makes a good fit with distributive policy, and traditional public administration is

Table 1. Policy Type and Proper Management Paradigm

\begin{tabular}{l|l}
\hline \multicolumn{1}{c|}{ Policy type } & \multicolumn{1}{c}{ Proper management paradigm } \\
\hline Regulatory & New public administration \\
\hline Distributive & $\begin{array}{l}\text { Networked governance } \\
\text { New public management (Customer-oriented practices) }\end{array}$ \\
\hline Redistributive & Traditional public administration \\
\hline Constituent & Traditional public administration \\
\hline
\end{tabular}


appropriate for both redistributive and constituent policy.

It is important to point out, however, that NPM should be used in only limited areas of distributive policy. NPM has often stressed relying on procedures for implementing government policies that are similar to those supposedly used in private market activities and business, on the basis of presumption that public and private organizations are adequately similar to make it possible to adopt similar techniques in both sectors (Barzelay, 2001; Kettl, 2002). And so NPM techniques should only be adopted in distributive policy areas that are comparable to private market settings. A good example of such a policy arena would be the U.S. Postal Service, which operates generally like business firm in a market (Rosenbloom, 1998, p. 477). Such a public organization has to invest in services for which there is powerful customer need and eliminate completely those without customer demand. Other distributive policy areas, however, call for extensive stakeholder participation in policy making. Thus, where the practice of public administration is not purely marketlike, networked governance, characterized by reliance on market mechanisms but featuring little distinction between politics and administration, would be the answer for government reformers.

\section{CONCLUSION AND FUTURE RESEARCH}

This article has explored how to resolve the problematic issue of the "one-size-fitsall" approach to public management paradigms by focusing on finding an appropriate management paradigm for particular policy arena(s) based on two critical elements of public administration - the politics-administration dichotomy and use of market mechanisms (Wilson, 1887). The study proposes that despite calls for an end to bureaucracy (or hierarchy) (Pinchot \& Pinchot, 1994; Thayer, 1973; Bevir, 2007), traditional public administration is an appropriate choice in the areas of redistributive and constituent policy. Moreover, new public administration works well for regulatory policy, whereas networked governance and NPM (i.e., its customer orientation) are the right answer in the arena of distributive policy. Overall, this maintains that an appropriate management approach is dependent on the types of public policy that public officials are supposed to implement (Rhodes, 1997; Keast et al., 2006; Jordan et al., 2005). Scholarly conversation on modern governance should be geared toward finding the mix of management paradigms that operates most efficiently in a given policy area. As Rhodes (1997, p. 139) has stated, "It's the mix that matters." However, the mix should be dependent on the configuration of different policies that the government implements. In order that public administrators are able to select the best management for implementing their policies, it is critical for reformers or political leaders to delegate the authority that will 
enable them to surmount the one-size-fits-all approach to government reform.

In the future, researchers can assess the empirical validity of the propositions suggested here. For example, multiple case studies would tell us whether or not a given policy type is critical to the success of the management paradigm. Moreover, although this article broadly describes a certain type of policy such as regulatory, distributive, and so on, for empirical studies it would be necessary to further specify types of policy (e.g., pollution regulation, personnel management, research grant, etc.). For this purpose, Ackroyd et al.'s (2007) study may provide us with a good model. They found that in the U.K., the effectiveness of NPM varied widely according to the area of public services-housing (presumably, distributive policy), social services (i.e., redistributive policy), and health care (i.e., redistributive policy). NPM was most successful in the area of housing, whereas it was less effective in social services and health care. One of their explanations for this is that compared with employees in social work and health care who have strong attachments to a "public service ethos," housing officers have consistently been exposed to the private sector and its values (p. 23). Thus, housing officers are better able to meet NPM objectives of efficiency and performance control, as well as customer satisfaction. Furthermore, it might be meaningful for future researchers to address policy arenas with mixed characteristics, such as one that contains features of distributive and regulatory policy — farm subsidies, for example — or of distributive and redistributive policy_for instance, urban mass transit (Spitzer, 1983, pp. 29-31). In these mixed policy arenas, it would be challenging for public administrators to adopt a single management paradigm or even to combine relevant multiple management paradigms. Finally, future researchers may want to consider other situational factors, such as organizational type in addition to policy type. A multiple regression analysis incorporating different situational factors would or would not verify the validity of the policy type variable. The results of such studies would suggest more sophisticated guidelines for effective implementation of public management paradigms.

\section{REFERENCES}

Ackroyd, S, Kirkpatrick, I., \& Walker, R. M. 2007. Public management reform in the UK and its consequences for professional organization. Public Administration, 85(1): 9-26.

Aldridge, R., \& Stoker, G. 2002. Advancing a public service ethos. London: New Local Government Network.

Alford, J., \& Hughes, O. 2008. Public value pragmatism as the next phase of public Management. American Review of Public Administration, 38(2): 130-148. 
Appleby, P. 1949. Policy and administration. University of Alabama Press.

Barzelay, M. 2001. The new public management: Improving research and policy dialogue. Berkeley, CA: University of California Press.

Beetham, D. 1987. Bureaucracy. Stony Stratford, UK: Open University Press.

Behn, R. D. 1998. The new public management paradigm and the search for democratic accountability. International Public Management Journal, 1(2): 131-164.

Bevir, M. 2007. What is governance? In M. Bevir (ed.), Public governance. Vol. 1: Theories of Governance. London: Sage.

Dahl, R. 1947. The science of public administration: Three problems. Public Administration Review, 7(1): 1-11.

Daley, D. 1984. Controlling the bureaucracy among the states. Administration and Society, 15 (4): 475-488.

deLeon, L., \& Denhardt, R. B. 2000. The political theory of reinvention. Public Administration Review, 60(2): 89-97.

Denhardt, R. B. 1999. Public administration: An action orientation. Orlando, FL: Harcourt Brace.

Denhardt, R. B., \& Denhardt, J. V. 2003. The new public service: An approach to reform. International Review of Public Administration, 8(1): 2-10.

Dunleavy, P., Margetts, H., Bastow, S., \& Tinkler, J. 2005. New public management is dead-Long live digital-era governance. Journal of Public Administration Research and Theory, 16(3): 467-494.

Epstein, D., \& O'Halloran. S. 1999. Delegating powers: A transaction cost politics approach to policy making under separate powers. New York: Cambridge University Press.

Evans, J. W. 1981. A new administrative ethic? Attitudes of public managers and students. Public Personnel Management, 10(1): 132-139.

Forester, J. 1984. Bounded rationality and the politics of muddling through. Public Administration Review, 44(1): 23-31.

Frederickson, H. G. 2010. Social equity and public administration: Origins, developments, and applications. Armonk, NY: M. E. Sharpe.

Goodnow, F. J. 1900. Politics and administration. New York: Macmillan.

Goodsell, C. T. 1981. Looking once again at human service bureaucracy. Journal of Politics, 43(3): 763-778.

Goss, S. 2001. Making local governance work. London: Macmillan.

Guy, M. E. 1989. Minnowbrook II: Conclusions. Public Administration Review, 49(2): 219-220.

Hood, C., Scott, C., James, O., Jones, G. W., \& Travers, A. 1999. Regulation inside government: Waste-watchers, quality police and sleaze-busters. Oxford: Oxford 
University Press.

Hood, C., \& Peters, G. 2004. The middle aging of new public management: Into the age of paradox? Journal of Public Administration Research and Theory, 14(3): 267-282.

Jones, C. 2001. Voices from the front line: State social workers and new labour. British Journal of Social Work, 31(4): 547-562.

Jones, L. R., \& Thompson, F. 1999. Public management: Institutional renewal for the twenty-first century. Stamford, CT: Elsevier-JAI Press.

Jordan, A., Wurzel, R. K. W., \& Zito, A. 2005. The rise of "new" policy instruments in comparative perspective: Has governance eclipsed government? Political Studies, 53(3): 477-496.

Kaboolian, L. 1998. The new public management: Challenging the boundaries of the management vs. administration debate. Public Administration Review, 58(3): 189-193.

Keast, R., Mandell, M., \& Brown, K. 2006. Mixing state, market and network governance modes: The role of government in "crowded" policy domains. International Journal of Organization Theory and Behavior, 9(1): 27-50.

Kettl, D. F. 2002. The transformation of governance. Baltimore, MD: Johns Hopkins University Press.

Kickert, W. J. M. 1997. Public governance in the Netherlands: An alternative to AngloAmerican managerialism. Public Administration, 75(4): 731-753.

Kim, J., \& Kaneko, Y. 2011. Social service contracting-out in Korea and Japan: Municipal governments, nonprofit contractors, and local residents. Korean Journal of Policy Studies, 26(1): 145-187.

Kim, Y. 2007. Differentiation of bureaucracies and their responses to reform. $\mathrm{PhD}$ diss.. Cornell University.

Kim, Y. 2010. The New Public Management (NPM) and its limitations. Korean Governance Review, 17(3): 179-195.

Light, P. 1993. Monitoring government inspectors general and the search for accountability. Washington, DC: Brookings.

Long, N. 1949. Power and administration. Public Administration Review, 9 (3): 257264.

Lowi, T. J. 1972. The four systems of policy, politics and choice. Public Administration Review, 32(4): 298-310.

Lowi, T. J. 1979. The end of liberalism: The second republic of the United States (2nd ed.). New York: Norton.

Lowi, T. J. 1985. The state in politics: The relation between policy and administration. In Roger G. Noll (ed.), Regulatory Policy and the Social Sciences (pp.). Berkeley: 
University of California Press.

Marini, F. 1971. Toward a new public administration. Scranton, PA: Chandler Publications.

McCool, D. 1990. Subgovernments as determinants of political viability. Political Science Quarterly, 105(2): 269-294.

Meier, K. J. 1993. Politics and the bureaucracy: Policymaking in the fourth branch of government. Pacific Grove, CA: Brooks/Cole Publishing.

Moore, M. 1995. Creating public value. Cambridge, MA: Harvard University Press.

Pinchot, G., \& Pinchot, E. 1994. The end of bureaucracy and the rise of intelligent organization. San Francisco: Berrett-Koehler.

Pollitt, C., Birchall, J., \& Putnam, K. 1998. Decentralizing public service management. London: Macmillan.

Rainey, H. G. 2003. Understanding and managing public organizations. San Francisco: Jossey-Bass.

Redford, E. S. 1969. Democracy in the administrative state. New York: Oxford University Press.

Rhodes, R. A. W. 1997. From marketisation to diplomacy: It's the mix that matters. Australian Journal of Public Administration, 56(2): 40-53.

Rosenbloom, D. H. 1998. Public administration. McGraw-Hill.

Syrett, V., Jones, M., \& Sercombe, N. 1997. Implementing community care: The congruence of manager and practitioner cultures. Social Work and Social Sciences Review, 7(3): 154-169.

Smith, R. 2003. Focusing on public value: Something old and something new. Victoria, Australia: Monash University.

Spitzer, R. J. 1983. The presidency and public policy: The four arenas of presidential power. University: University of Alabama Press.

Stoker, G. 2006. Public value management: A new narrative for networked governance? American Review of Public Administration, 36(1): 41-57.

Terry, L. D. 1993. Why we should abandon the misconceived quest to reconcile public entrepreneurship with democracy. Public Administration Review, 53(4): 393395.

Thayer, F. 1973. An end to hierarchy! An end to competition! New York: Viewpoints.

Thompson, F. J., \& Riccucci, N. M. 1998. Reinventing government. Annual Review of Political Science, 1:231-257.

Waldo, D. 1948. The administrative state: A study of the political theory of American public administration. New York: Ronald Press.

Waldo, D. 1971. Public administration in a time of turbulence. Scranton, PA: Chandler Publications. 
Walker, R. M. 2001. How to abolish public housing: Implications and lessons from public management reform. Housing Studies, 16(5): 676-696.

Walker, R. M., \& Enticott, G. 2004. Using multiple informants in housing studies: Methodological issues and prescriptions for research. Paper presented at the Asia-Pacific Network for Housing Research, Hong Kong, February.

Wilson, W. [1887] 1941. The study of administration. Political Science Quarterly, 56(2): 197-222. 